\title{
Groundwater uptake of different surface cover and its consequences in great Hungarian plain
}

\author{
Zoltán Gribovszki ${ }^{*} \mathbb{B}$, Péter Kalicz ${ }^{1}$, Kitti Balog ${ }^{2}$, András Szabó ${ }^{3}$, Tibor Tóth², Péter Csáfordi², \\ Mohamed Metwaly ${ }^{4,5}$ and Sándor Szalai ${ }^{6}$
}

\begin{abstract}
Introduction: Forest cover in Hungary has increased from 1.1 to 2.0 million hectares during the last century. The EU (European Union) promotes further afforestation; thus, 15,000-18,000 ha are being forested each year, mainly in the Hungarian Great Plain. In terms of species used for afforestation, poplar plantations are preferred over native oak woodlands.

The groundwater uptake of trees can be a significant water balance element of forested areas in shallow groundwater environments within the Hungarian Great Plain. Forests can cause water table depressions and subsurface salt accumulation in areas with negative water balance. This study examined the hydrological impact of forest cover in the Hungarian Great Plain. Within the framework of this research, climatic water balance, water table depth and salinity, subsoil layering, tree species and stand age were analysed as influencing factors. This paper compares the effect which an oak forest, a poplar plantation and a pasture have on groundwater uptake and salt accumulation.

Results: The water table level was roughly $0.4-0.5 \mathrm{~m}$ lower beneath the oak forest and the poplar plantation than it was beneath the pasture. Forest groundwater use was 1.5-2 times higher than that of grassland. Groundwater uptake of oak forest was greater than that of poplar plantation during the monitoring period. Salt accumulation, which shows water use in the longer run, was slightly higher for poplar in deeper layers.

Conclusions: The greater amount of groundwater used by trees does not lead to a higher salt uptake as only a slight accumulation of salt was measured beneath the forests. Overall, hybrid poplar was slightly less favourable than native oak when considering salinization effects. However, even greater groundwater uptake by trees over longer timescales could cause more significant salt accumulation under pronounced drought conditions due to climate change.
\end{abstract}

Keywords: Groundwater recharge/water budget, Evapotranspiration, Diurnal fluctuation, Forest cover, Salinization

\section{Introduction}

Most of the 700,000 ha of afforestation being planned in Hungary (Andrasevits et al. 2005) with EU support will be on areas that cannot support profitable field crop cultivation. Based on topsoil analyses of formerly forested areas, Führer and Járó (2005) stated that the Hungarian Great Plain could be the most important area for afforestation. However, the Hungarian Great Plain is also the place where recent climate and surface soil moisture

\footnotetext{
* Correspondence: zgribo@gmail.com

${ }^{1}$ Institute of Geomatics and Civil Engineering, University of Sopron, Sopron, Hungary

Full list of author information is available at the end of the article
}

conditions are generally not adequate for forests; therefore, most forest ecosystems can survive only by utilising subsurface water surplus from shallow groundwater.

In shallow water table areas, forest vegetation can change the water-salt balance of the soil (Nosetto et al. 2007) and these effects are manifested in the lowering of the water table (Sun et al. 2000; Major 2002) and in an increase in the salt concentration of certain soil and subsoil layers (Nosetto et al. 2008).

In sub-humid environments, like the Hungarian Great Plain, afforestation can modify the water and the salt balance (Jobbágy and Jackson 2004; Nosetto et al. 2007), not only causing decline in the level of the water table 
(Sun et al. 2000; Major 2002) but also inducing salinization (Nosetto et al. 2008).

Planted forests can achieve higher biomass production in areas with shallow, reachable water table, but they often introduce salinization of soil and groundwater resources due to their greater transpiration (Jobbágy and Jackson 2004) (Fig. 1).

Different factors affecting salt accumulation in forested areas established over shallow water tables were examined (Nosetto et al. 2008) and evaluated in the Argentine Pampas and East Hungary (Nosetto et al. 2007). Nosetto et al. (2008) also developed a conceptual model for salinization effect of afforestation. In their model, the following main factors have an influence on salt accumulation: the climatic water balance (the more negative is the difference between precipitation $[\mathrm{P}]$ and potential evapotranspiration [PET], the stronger the salinization process); hydrogeology (restricting the extent of salinization where groundwater resources are available at significant rates to plants) and biological factors (influencing evapotranspiration rate and salt tolerance of the tree species).

Forest ET (evapotranspiration) is generally higher than the ET of neighbouring grasslands because of the enhanced LAI and root depth of the woody vegetation (Calder 1998; Nosetto et al. 2005).

Mátyás and Sun (2014) found that afforestation might be negative from the viewpoint of water resources. Forest plantations generally reduce stream flow and lower the water table level because their water use is higher than the previous land cover types they are replacing. Higher evaporation potential due to climate change (e.g. warming and/or extreme drought events) is likely to reduce areas that are appropriate for tree growth and forest establishment, especially in areas that have an aridity index higher than unity. The ratio of potential evaporation to precipitation is known as the aridity or dryness index (Budyko 1974). Areas where the aridity index is greater than unity are commonly classified as dry (Arora 2002).

The abovementioned properties of forests are also true in the sub-humid climate of the Hungarian Great Plain where there is not enough precipitation to support woody vegetation; thus, trees survive dry periods by using groundwater (Ijjász 1939; Magyar 1961). Magyar (1961) found that it takes seedling roots 3 years to attain the $3.5-\mathrm{m}$ root depth needed to access the water table, while root depths of $5.15 \mathrm{~m}$ can be detected in elm seedlings 2 years after planting in a moderate saline environment.

A good example for comparing the water balance of different land uses is the analysis of Móricz et al. (2012) in Nyírség. In that paper, a common oak forest has 30\% more ET (758 mm/year) than a neighbouring fallow $(623 \mathrm{~mm} /$ year). Moreover, the groundwater use difference of various vegetation types (expressed in depth of water equivalent to rainfall, oak $243 \mathrm{~mm}$ /year, fallow $85 \mathrm{~mm} /$ year) is quite significant (threefold). Groundwater consumption was close to $60 \%$ of the total transpiration in the case of the oak forest and approximately $30 \%$ in the case of the fallow plot. In the growing season of the wet year, groundwater consumption was approximately $40 \%$ less than in the dry year despite the deeper dry-season groundwater level. Thus, during the dry growing season, both vegetation covers relied considerably on the available groundwater resources.

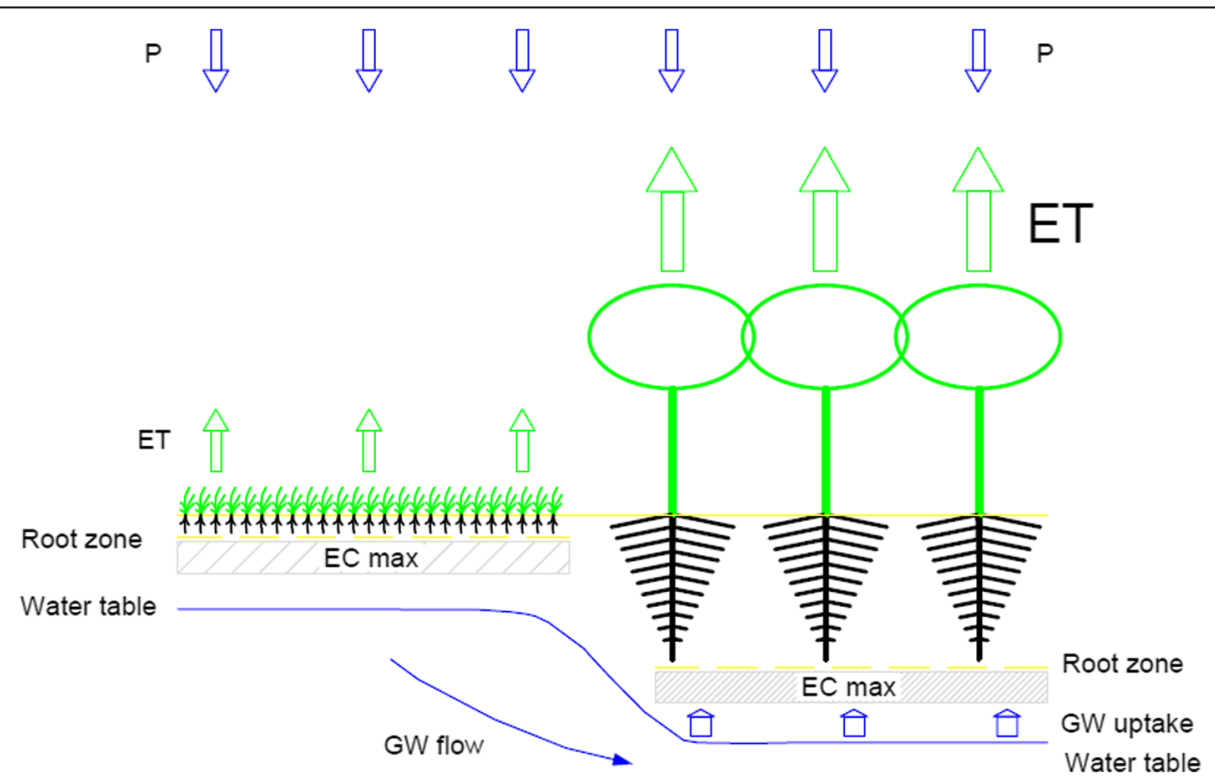

Fig. 1 Forest vegetation impact on water-salt balance in a shallow groundwater environment, after Szabó et al. (2012). ET evapotranspiration, $P$ precipitation, EC electrical conductivity 
The groundwater level under forests is deeper throughout the year than it is under grasslands, but the difference between the two land covers is greater in the growing season (Ijjász, 1939). Jobbágy and Jackson (2007) stated that the groundwater level difference can be as much as $75 \mathrm{~cm}$ in the Argentinean Pampas. Major (2002) observed that within a 2-km-wide belt, mainly dominated by coniferous forest compartment in the Danube-Tisza Sand Plateau of the Hungarian Great Plain, the groundwater level can be as much as $0.8-$ $1.1 \mathrm{~m}$ deeper than under the neighbouring non-forested areas. In shallow groundwater areas of the Danube-Tisza Sand plateau, Szodfridt and Faragó (1968) found that rooting depth of forest vegetation generally descends 50-60 cm deeper than herbaceous vegetation to reach the water table. But these authors also stated that only sparse herbaceous vegetation can survive under natural conditions in the sites where the groundwater level (in April) is deeper than $2.5 \mathrm{~m}$.

Szilágyi et al. (2012) analysed actual ET (by linear transformation of the MODIS daytime land surface temperature) in the Danube-Tisza Sand Plateau. The largest ET, on average $505 \mathrm{~mm} /$ year, was found over deciduous forests (meanwhile the regional annual precipitation was $550 \mathrm{~mm}$ ). In some groundwater discharge areas (mostly shallow groundwater areas) where forest cover can be detected, ET was 70-80 mm/year more than precipitation. This negative water balance of forests creates a local depression in the water table forcing groundwater to flow towards it.

The main objective of this study was to estimate the hydrological impact of afforestation by comparing the water and salt balances of a neighbouring grassland, a hybrid poplar plantation and an oak forest in the Hungarian Great Plain. The question is an important one since the EU actively promotes afforestation and 15-18,000 ha are being forested in Hungary each year. Hybrid poplar is the most planted forest type in shallow groundwater areas of the Hungarian Great Plain because of its profitability. Key questions are generally the following: What will be the effects of afforestation on the water-salt balance of the target area, and, second, do poplar plantations have similar or significantly different effects than native oak woodlands?

\section{Methods}

A detailed investigation of afforestation in the Hungarian Great Plain is being carried out through the systematic study of factors such as climatic water balance, water table depth and salinity, tree species, subsoil layering and stand age (in the frame of OTKA NN 79835 project). At the regional scale, 108 forested and nearby non-forested plots are sampled. At the stand scale, 18 representative forested sites and associated non-forested sites (from the 108) are monitored intensively (Tóth et al. 2014). In this paper, datasets of three neighbouring plots (a common oak forest, a poplar plantation and a grass site) in Jászfelsőszentgyörgy are compared (Fig. 2). While a water and salt dynamic comparison of an oak and a pasture ecosystem has been published (Gribovszki et al. 2014), this paper substantially broadens that analysis by including results from a hybrid poplar plantation.

\section{Site characteristics and data sampling}

The study area is located in the northern part of the Hungarian Great Plain (lat 47.480736, long 19.773792). The ground surface is flat, and the study plots are far from surface water bodies. The soil is loess covered sandy alluvial sediments. The oak forest (Quercus robur) is 56 years old and $22 \mathrm{~m}$ high $\left(200 \mathrm{~m}^{3} /\right.$ ha biomass $)$; the hybrid poplar plantation (Populus $x$ euramericana $c v$. OP229) is only 13 years old $\left(155 \mathrm{~m}^{3} /\right.$ ha biomass) but is almost as tall as the oak forest. History of surface cover characteristics of sample areas is presented in Table 1. The grass-covered area is managed as a pasture. The area has a continental climate. The annual precipitation is $550 \mathrm{~mm}$ (Dövényi 2010). The Budyko aridity index (Budyko 1974) is about 1.3 in the vicinity of the sites (Bussay et al. 2012). The analysed period was extremely dry and hot comparing daily mean temperatures in the growing season $\left(2012\right.$ : $23.6{ }^{\circ} \mathrm{C}$ ) with the 30-year longterm average $\left(17.5{ }^{\circ} \mathrm{C}\right)$. The spring and summer of 2012 was almost rainless; therefore, the near-surface soil moisture content was very low.

GW (groundwater) wells with depths of $6 \mathrm{~m}$ were installed in the poplar plantation (F12), the common oak forest (F13) and the grass-covered pasture (F14). The PVC well casing had a diameter of $63 \mathrm{~mm}$ and was screened at the bottom $5 \mathrm{~m}$ starting $1 \mathrm{~m}$ below the surface.

Soil sampling was performed once and was scheduled for the late summer and early fall (September to October) when water table levels were the lowest. Soil sampling was performed to the depth of groundwater table $+1 \mathrm{~m}$. "Soil" as used in this paper includes the vadose zone. Samples were taken at every $20 \mathrm{~cm}$ from the topsoil $(0-1 \mathrm{~m})$ and at every $50 \mathrm{~cm}$ below $1 \mathrm{~m}$ depth. The soil layers of the plots can be seen on Fig. 2. The soil texture classes are typically loam, sandy loam and loamy sand. The method of Loheide et al. (2005) was used for specific yield (Sy) estimation, based on texture analysis (particle distribution curve) of the soil samples. A readily available Sy value of 0.05 was determined for the oak and the grass sites, while 0.1 was determined for the poplar site.

To determine the salt accumulation, electrical conductivity (EC) of the groundwater was measured in the field, EC measurements were performed on soil samples 
Jaszfelsoszentgyorgy

Geomorphological and Land Use Map

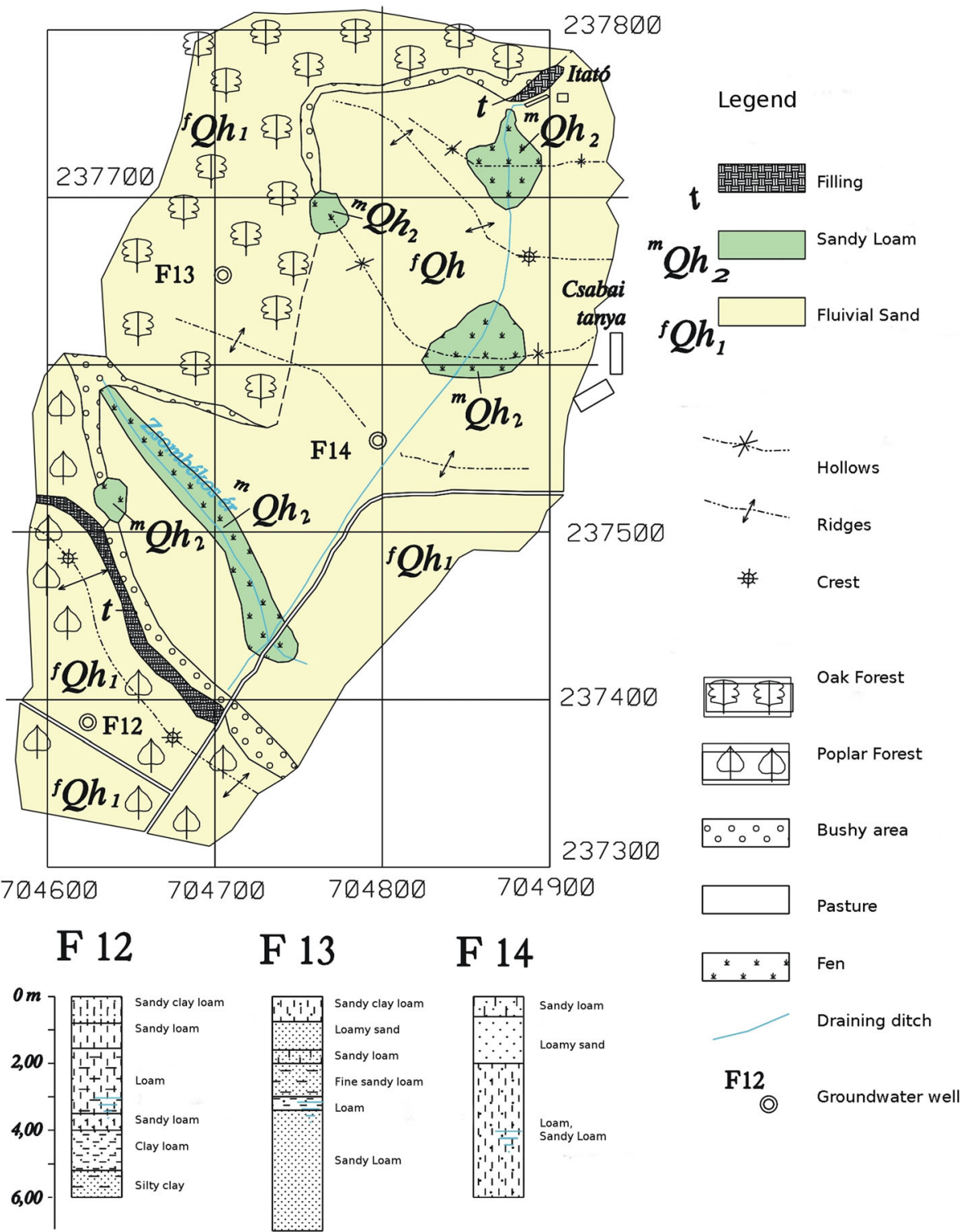

Fig. 2 Geo-morphological map with land use and location of groundwater wells

Table 1 History and present state of sample areas

\begin{tabular}{lllllllll}
\hline Stand & $\begin{array}{l}\text { Dominant } \\
\text { species }\end{array}$ & Age (year) & LAl & LC (1782-1785) & LC (1819-1869) & LC (1872-1884) & LC (1950) \\
\hline Oak & Quercus robur & 56 & 6.8 & Pasture & Forest & Pasture & $\begin{array}{l}\text { Scrub and herbaceous } \\
\text { vegetation }\end{array}$ & Forest \\
Poplar & Hybrid poplar & 13 & 5.9 & Pasture & $\begin{array}{l}\text { Scrub and } \\
\text { herbaceous } \\
\text { vegetation }\end{array}$ & Pasture & Forest & Forest \\
Pasture & Grass & - & 3.3 & Pasture & Pasture & Pasture & Pasture & Pasture
\end{tabular}

LC land cover, LAl leaf area index from field measurement, LANDSAT and MODIS products 
in the laboratory. These former parameters were calculated to the reference saturation extract electrical conductivity (Kijne et al. 1988).

GW wells were instrumented with vented pressure transducers (www.dataqua.hu) that measure groundwater level at 15 min sampling intervals. A meteorological station was installed in the vicinity on a pasture in July 2012 and collected standard meteorological parameters (e.g. temperature, relative humidity, net radiation, wind speed, and precipitation) every $5 \mathrm{~min}$. The measurement period was relatively short (start: 09.07.2012, end: 03.08.2012), because of failure of water table measurement sensors.

\section{Diurnal-based ET calculation method}

The riparian-zone groundwater ET technique (Gribovszki et al. 2008) was used to estimate groundwater uptake by trees. This calculation, which is a further development of the original White (1932) method, is based on the diurnal fluctuations of groundwater levels.

This ET-estimation method employs the water balance equations written for the saturated zone:

$$
\frac{\partial S}{\partial t}=S_{y}(t, h) \frac{\partial h}{\partial t}=Q_{i}-Q_{o}-E T_{\mathrm{gw}}=Q_{\mathrm{net}}-E T_{\mathrm{gw}}
$$

where $\partial S / \partial t\left[\mathrm{~L}^{3} \mathrm{~T}^{-1}\right]$ is the groundwater storage $(S)$ change in time $(t), h[\mathrm{~L}]$ is the hydraulic head (groundwater level) in the riparian zone, $S_{y}$ is the specific yield, $Q_{i}$ is the incoming discharge $\left[\mathrm{L}^{3} \mathrm{~T}^{-1}\right]$ to the unit land area, while $Q_{o}$ is the outgoing discharge from the unit land area $\left[\mathrm{L}^{3} \mathrm{~T}^{-1}\right]$. The net supply/replenishment rate is the difference of the incoming and outgoing discharges, $Q_{\text {net }}=Q_{i}-Q_{o},\left[\mathrm{~L}^{3} \mathrm{~T}^{-1}\right] . \mathrm{ET}_{\mathrm{gw}}$ is the evapotranspiration from the groundwater.

To obtain the net supply rate $\left(Q_{\text {net }}\right)$, an empirical submethod (based on characteristic points) was used (Fig. 3). The technique has the following steps:

1. The maximum of $Q_{\text {net }}$ was calculated for each day by selecting the largest positive time-rate of change value in the groundwater level readings, such as $Q_{\text {net }}=S_{y}$ $\Delta h / \Delta t$.

2. The minimum of $Q_{\text {net }}$ was obtained by calculating the mean of the smallest time-rate of change in $h$ taken in the predawn/dawn hours. The averaging was necessary to minimise the relatively large measurement error when the changes were small.

3. The resulting values of the $Q_{\text {net }}$ extrema then were assigned to those temporal locations where the groundwater level extrema took place (the first point to the time of the water table maxima, the second point to the temporal location of the minima water table in a given day).

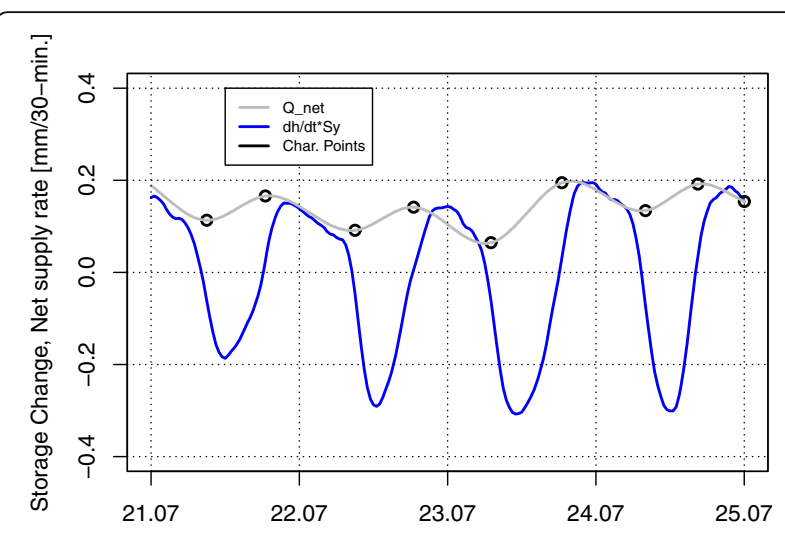

Fig. 3 Graphical representation of the method for $\mathrm{ET}_{\text {gw }}$ calculation. The blue line is the time derivative of groundwater level multiplied by specific yield $\left(\partial \mathrm{h} / \partial \mathrm{t}^{*} \mathrm{~S}_{\mathrm{y}}\right)$ representing storage change. Dots are characteristic points; the grey line represents net supply rate $\left(Q_{\text {net }}\right)$

4. This was followed by a spline interpolation of the $Q_{\text {net }}$ values to derive intermediate values between the specified extrema (Gribovszki et al. 2008).

5. Knowing the $Q_{\text {net }}$ values the $\mathrm{ET}_{\mathrm{gw}}$ rates can be obtained by rearranging the former water balance equation as

$$
\mathrm{ET}_{\mathrm{gw}}=Q_{\mathrm{net}}-S_{y} \frac{\partial h}{\partial t}
$$

As a comparative reference, ET values PenmanMonteith ET (ET_PM) rates were calculated for short grass reference surfaces from a meteorological dataset (Allen et al. 1998).

$$
\mathrm{ET}_{\mathrm{PM}}=\frac{\Delta\left(R_{0}-S\right)+\rho c_{p} \mathrm{VPD} r_{a}^{-1}}{L_{v}\left[\Delta+\gamma \cdot\left(1+r_{c} r_{a}^{-1}\right)\right]}
$$

where $\mathrm{ET}_{\mathrm{PM}}$ is the Penman-Monteith ET in millimeter time-step $^{-1}, L_{v}$ is the latent heat of vaporisation (MJ kg $\left.{ }^{-1}\right), \Delta$ is the slope of the saturation vapour pressure curve $\left(\mathrm{kPa}^{\circ} \mathrm{C}^{-1}\right), \gamma$ is the psychrometric constant $\left(\mathrm{kPa}{ }^{\circ}\right.$ $\left.\mathrm{C}^{-1}\right), R_{O}$ is the net radiation ( $\mathrm{MJ} \mathrm{\textrm {m } ^ { - 2 }}$ time-step ${ }^{-1}$ ), VPD is the vapour pressure deficit $(\mathrm{kPa}), S$ is the soil heat flux and temporary storage of energy into the tree itself (M) $\mathrm{m}^{-2}$ time-step $\left.{ }^{-1}\right), \rho$ is the air density $\left(\mathrm{kg} \mathrm{m}^{-3}\right), c_{p}$ is the specific heat of moist air $\left(\mathrm{kJ} \mathrm{kg}^{-1}{ }^{\circ} \mathrm{C}^{-1}\right), r_{a}$ is the aerodynamic resistance $\left(\mathrm{s} \mathrm{m}^{-1}\right)$ and $r_{c}$ is the bulk canopy resistance $\left(\mathrm{s} \mathrm{m}^{-1}\right)$.

The ET calculations and statistical analysis were performed using the R free software (R Core Team 2012).

\section{Results and discussion}

\section{Water table differences}

Water table depression can be detected under the oak forest and the poplar plantation next to a pasture, which indicates an increased groundwater use by the forests 
(Fig. 4). Differences in water table levels from the surface were $0.44 \mathrm{~m}$ (oak grass) and $0.36 \mathrm{~m}$ (poplar-grass) on average during July 2012 (Fig. 4), indicating a depression in the water table beneath the trees. The magnitude of the differences was similar to the water table depression determined during the growing season by Nosetto et al. (2007) on a planted oak forest and adjacent grassland in the Hortobágy region $(0.26-0.60 \mathrm{~m})$ and those determined by Móricz et al. (2012) by comparing an oak stand and a fallow plot in Nyírség $(0.5-0.6 \mathrm{~m})$. Both regions (Hortobágy and Nyirség) are also located in the Hungarian Great Plain.

The sinks of the water tables were the following for the sampled period: $0.35 \mathrm{~m} /$ month for pasture, similar $(0.37 \mathrm{~m} /$ month $)$ for oak and slightly greater $(0.46 \mathrm{~m} /$ month) for poplar. The higher water table recession for poplar was caused by the relatively higher elevation (105.53 m.a.s.l) of the poplar plantation. The oak forest occupied the lowest elevation (104.54 m.a.s.l); therefore, the recession should be the lowest here, but the difference between the pasture (105.00 m.a.s.l) and oak recession was minimal. Hence, all of the abovementioned differences in recession were modified by the vegetation groundwater uptake, and this groundwater use enhanced the recession validity for the given elevation. It should be noted that the analysed period was after an exeptionally dry spring. Thus, the water table was almost at its lowest point. (This is close to the very end of the general groundwater recession curve where further decay is very slow). This situation is best demonstrated by comparing of absolute water table elevations of different sites (Fig. 5).

Figures 4 and 5 show diurnal fluctuations of the water table. These fluctuation patterns are interrupted by rainfall at all places (e.g. July 11), but it is not caused by additional recharge (water table was relatively deep), probably induced by temporary reduction of vegetation groundwater uptake (Figs. 4 and 5).

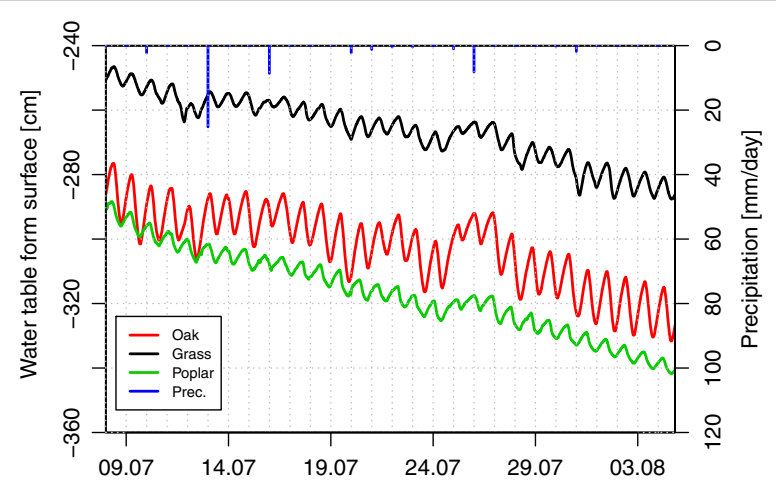

Fig. 4 Water table from the surface under the three different vegetation types in the summer of 2012

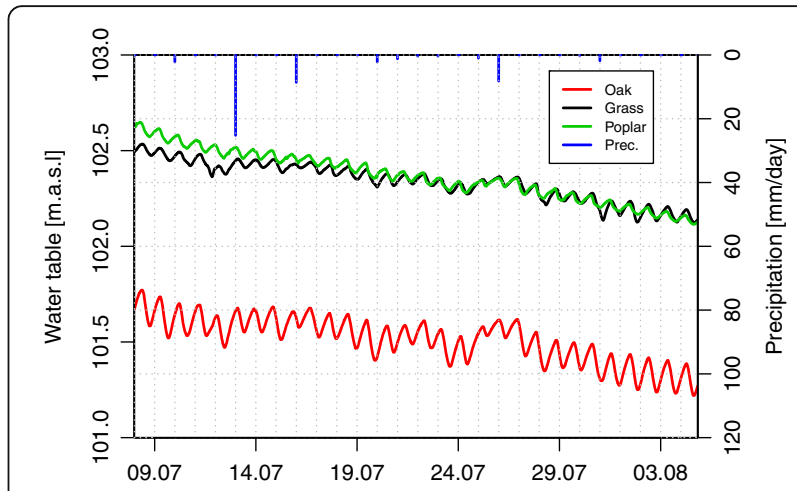

Fig. 5 Water table in meters above sea level under the three different vegetation types in summer of 2012

\section{Comparison of ET values}

Figure 6 shows ET rates calculated with 30-min frequency for a representative time period. On Fig. 7, ET rates with daily scale related to Pennman-Monteith reference ET can be seen.

Groundwater uptake of the oak site (mean $7.3 \mathrm{~mm} /$ day) was a bit higher than ET_PM (mean $6.5 \mathrm{~mm} /$ day). In the case of poplar vegetation, the $\mathrm{ET}_{\mathrm{gw}}$ (mean $5.4 \mathrm{~mm} /$ day) was lower than in the case of the oak. Grass $\mathrm{ET}_{\mathrm{gw}}$ (mean $3.4 \mathrm{~mm} /$ day) was less than a half of the oak and more than $2 \mathrm{~mm} /$ day lower than that of the poplar. It is important to highlight that the poplar plantation was younger (13 vs. 59 years old) and had less LAI (leaf aera index) and tree biomass than the oak forest.

ET values were higher than the potential ET calculated for some days at the oak site. The potential ET value was calculated for a grass reference surface. If the calculation of potential ET had been conducted for rougher surface conditions and for higher LAI of the forest, the ET values would have been higher because of the greater atmospheric and canopy conductance of the forest canopy. Poplar had lower LAI and roughness and thus lower potential to transpiration than oak. Grass had much lower potential for ET because its height and LAI

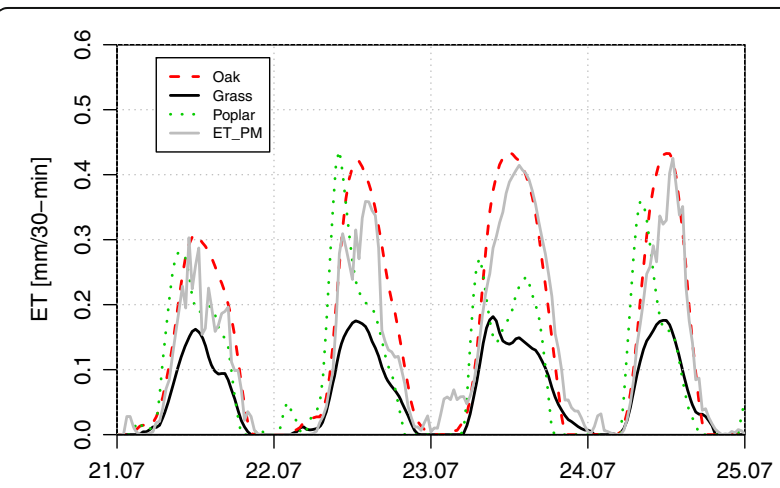

Fig. 6 ET rates in 30-min frequency (ET_PM means Pennman-Monteith ET) 


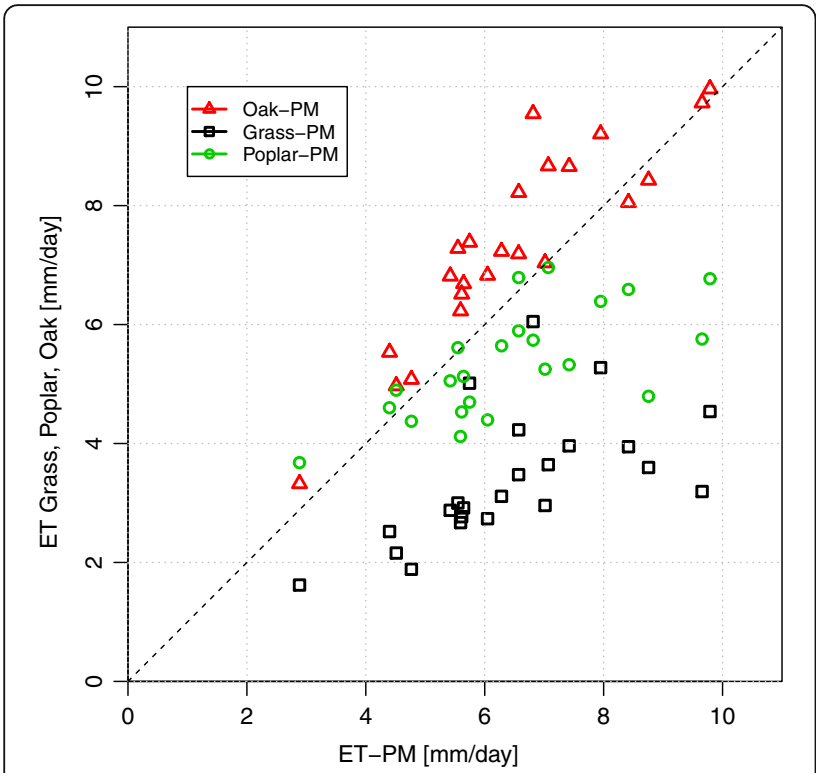

Fig. 7 ET rates of different surface covers compared to PennmanMonteith ET (ET_PM)

are the lowest from the three vegetation types. Moreover, it probably had limited groundwater access as well due to its shallower root depth.

Groundwater uptake values were large, but the data seem to be acceptable taking into account that the period of the analyses was exceptionally warm. Also, by July of 2012, the soil profile had already lost almost all of the stored moisture of the preceding periods. It is also noteworthy that the area possesses a dry and warm environment (therefore, the oasis effect (Morton 1983) can also enhance ET).

For comparison, in Hortobágy, Nosetto et al. (2007) determined an average of $1.9 \mathrm{~mm} /$ day (up to $3.2 \mathrm{~mm} /$ day) $\mathrm{ET}_{\mathrm{gw}}$ for an oak forest, also on the basis of water table diurnal fluctuation. In that study, the water table was significantly lower (on average $5 \mathrm{~m}$ from the surface) and the measurement period was in autumn. Therefore, higher values are possible in our case. Butler et al. (2007) calculated $\mathrm{ET}_{\mathrm{gw}}$ rates (using also diurnal method) of $2.9-9.3 \mathrm{~mm} /$ day for mixed vegetation types with groundwater depths between 0.3 and $3.4 \mathrm{~m}$ from the surface. In that study, the calculated $\mathrm{ET}_{\mathrm{gw}}$ rates were close to the total ET as reported in our case.

The correlation values between ET_PM and estimated groundwater ET rates are the following (Table 2).

The strongest correlations (also for 30-min and daily scales) between Oak_ET and ET_PM showed that these parameters are very similar. This suggests that Oak_ET reached the maximum potential ET, and the water was mostly taken up from groundwater according to the meteorological constraint in this dry period. The better correlations at the 30-min scale indicate that the curves had
Table 2 Correlation coefficients ( $r$ ) between reference ET_PM and estimated $\mathrm{ET}_{\mathrm{gw}}$ values

\begin{tabular}{lll}
\hline Stand & 30-min scale & Daily scale \\
\hline Oak-PM & $0.95^{*}$ & $0.90^{*}$ \\
Poplar-PM & $0.87^{*}$ & $0.67^{*}$ \\
Pasture-PM & $0.83^{*}$ & $0.59^{*}$
\end{tabular}

Oak-PM, poplar-PM and pasture-PM mean correlation between reference ET (PM_ET) and ETgw of oak site, poplar site and grass site, respectively *Significance of $r$ is less than 0.01

similar shapes during the day (Fig. 6). The lowest correlation of grass at the daily scale shows a lower correlation of Pasture_ET with meteorological factors. Grass root systems are probably not adequate to take up as much groundwater as the root systems of forests. For poplar, the correlation coefficients were between the values of oak and grass stands (Table 2). The lower correlations of poplar and grass compared to oak with ET_PM are more pronounced at high ET rates (very hot days with ET over $8 \mathrm{~mm} /$ day) (Fig. 7).

\section{Salt accumulation}

Electric conductivity (electrical conductivity of reference saturation extract) in soil was measured to analyse salt accumulation (Fig. 8). The greatest differences in soil salt content between land cover types were detected in the upper part of the soil and at the depth of the water table

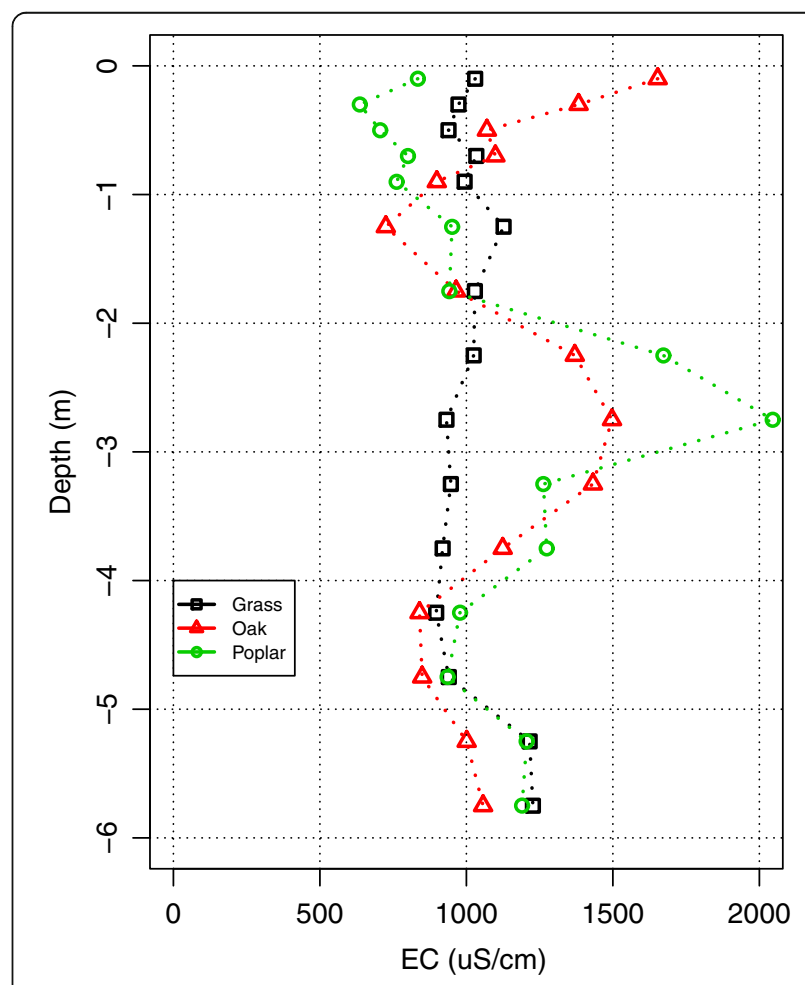

Fig. 8 Electrical conductivity (EC) profile of reference saturation extract under the pasture, the oak forest and the poplar plantation 
for forest sites. The specific conductivity values at $0.3-$ $0.5 \mathrm{~m}$ depth were higher for the oak forest site than they were for grassland site (difference $400-600 \mu \mathrm{S} / \mathrm{cm}$ ) and poplar (difference 600-800 $\mu \mathrm{S} / \mathrm{cm}$ ). These differences cannot be interpreted by present land cover but can be explained by considering previous land cover (see Table 1). The higher salt concentration under oak at the near-surface layers can be induced by earlier (in the middle of nineteenth century) forest cover. At that time, the large rivers of the Hungarian Great Plain were not regulated; therefore, the water table was much closer to the surface. Higher groundwater level constrained the salt accumulation (induced by forest vegetation with high ET) closer to the surface. At $1.25 \mathrm{~m}$, the conductivity was $200-400 \mu \mathrm{S} / \mathrm{cm}$ higher under the grass than under the forest sites. At around $3 \mathrm{~m}$ (the most typical water table depth under the forest sites), the soil contains more salt (diff. $600 \mathrm{us} / \mathrm{cm}$ for oak, $1100 \mathrm{us} / \mathrm{cm}$ for poplar) at forest sites than at the grassland. Below, the poplar plantation, the higher salt accumulation at approximately $3 \mathrm{~m}$ can be caused by the recent (twentieth century), more pervasive forest coverage. Before the oak forest plantation, the oak plot was only covered by grass and scrubs, but at the poplar plot, a black locust (Robinia pseudoacacia) forest had been established in the 1950s. For deeper soil layers, the salt contents and the tendency of the changes seemed to be similar under different land covers. As a comparison, Nosetto (2007) measured conductivity values in similar oak and grassland sites in Hortobágy. His values were 1.2-1.5 times higher than in this study. The vertical profile distribution was slightly different (Nosetto et al. 2007) showing significantly higher conductivity values for grass in the upper soil layers, which can be detected only to a lesser extent around $1 \mathrm{~m}$ in Jászfelsőszentgyörgy. The higher conductivities of lower soil layers (above the groundwater) for forests showed similar tendencies at Jászfelsőszentgyörgy and at Hortobágy.

The salt contents of the groundwater were also slightly greater under the forest plots (groundwater conductivities: oak-1023 $\mu \mathrm{S} / \mathrm{cm}$, poplar-1167 $\mu \mathrm{S} / \mathrm{cm}$ and pasture-960 $\mu \mathrm{S} /$ $\mathrm{cm})$. The present values of salt contents do not cause any problem for forest vegetation, but salt accumulation induced by future climate change may have more severe long-term effects for afforestation may. Nosetto et al. (2007) also detected a higher conductivity of groundwater under an oak forest than under grassland in Hortobágy, but the salt contents were notably higher--4900 $\mu \mathrm{S} / \mathrm{cm}$ and $2000 \mu \mathrm{S} / \mathrm{cm}$ for oak and for grassland sites, respectively. The cause of this notable difference is that soils on the study area of Hortobágy have finer texture (clayey soils); therefore, salinization effect is much stronger there than on our study sites with sandy soils.

\section{Conclusions}

The result of this study verified that forest vegetation has a strong influence on the water and salt balance of an area in a shallow groundwater environment. Hydrological characteristics of previous (during the last century) land uses (grassland, arable land) in the Hungarian Great Plain are significantly different from those of the forest. Vegetation with greater amount of total biomass requires more water to sustain, leading to higher transpiration rates and water uptake from the groundwater by deeply rooted trees in these relatively dry, shallow groundwater areas. Increased groundwater uptake results in water table depression under forest cover. Salt uptake is slower than that of water, consequently salt accumulation can be detected under forested sites in both the soil and groundwater. Groundwater uptake of middle-aged oak forests was greater than that of younger poplar plantations during the monitoring period. From another viewpoint, salt accumulation, which shows water use in the longer run, was slightly higher for poplar in both the vadose zone and groundwater. Therefore, hybrid poplar, which is the most strongly preferred species for afforestation campaigns, is slightly less favourable than native oak when considering salinization effects. Nevertheless, the measured differences in salt content are small compared to similar study results for clayey soils (Nosetto et al. 2007). However, when longer term climate change is taken into consideration, this salt accumulation process may reduce the vitality and the biological production of some vulnerable lowland tree species. Moreover, from water quality aspects, higher salt content of groundwater significantly reduces the utilisation of water resources for drinking and irrigation with serious economic, social and environmental consequences.

\section{Acknowledgements}

Research has been supported by the following funds: OTKA (NN 79835) and "Agrárklíma.2" (VKSZ_12-1-2013-0034) and EFOP-3.6.2-16-2017-00018 EU-national joint founded research project. This paper was also supported by the János Bolyai Scholarship of the Hungarian Academy of Sciences. The research of Zoltán Gribovszki was supported by the European Union and the State of Hungary, co-financed by the European Social Fund in the framework of TÁMOP 4.2.4. A/ 2-11-1-2012-0001 "National Excellence Program." The work of KB and PCS was supported by the Postdoctoral Research Programme PD-029/2015 of the Hungarian Academy of Sciences.

\section{Authors' contributions}

ZG, KB, ASZ, PCS and TT designed and evaluated the research. PK carried out programming, and MM and SSZ participated in geophysical analysis. All authors read and approved the final manuscript.

\section{Competing interests}

The authors declare that they have no competing interests.

\section{Publisher's Note}

Springer Nature remains neutral with regard to jurisdictional claims in published maps and institutional affiliations. 


\section{Author details}

Institute of Geomatics and Civil Engineering, University of Sopron, Sopron, Hungary. ${ }^{2}$ Institute for Soil Sciences and Agricultural Chemistry, Centre for Agricultural Research, Hungarian Academy of Sciences, Budapest, Hungary. ${ }^{3}$ Forest Research Institute, National Agricultural Research and Innovation Centre, Budapest, Hungary. ${ }^{4}$ Archaeology Department, College of Tourism and Archaeology, King Saud University, Riyadh, Saudi Arabia. ${ }^{5}$ National Research Institute of Astronomy and Geophysics (NRIAG), Cairo, Egypt. ${ }^{6}$ MTA CSFK GGI, Sopron, Hungary.

Received: 16 November 2016 Accepted: 11 October 2017 Published online: 06 November 2017

\section{References}

Allen, R.G., Pereira, L.S., Raes, D., Smith, M., (1998) Crop evapotranspiration--guidelines for computing crop water requirements, Vol. 56 of FAO Irrigation and Drainage. FAO, Rome, URL http:/www.fao.org/docrep/X0490E/x0490e06.htm

Andrasevits Z, Buzás GY, Schiberna E (2005) Current afforestation practice and expected trends on family farms in West Hungary. J Cent Eur Agric 5:297-302

Arora VK (2002) The use of the aridity index to assess climate change effect on annual runoff. J Hydrol 265:164-177

Budyko MI (1974) Climate and life. Academic Press, Orlando, FL

Bussay A, Tóth T, Juškevičius V, Seguini L (2012) Evaluation of aridity indices using SPOT normalized difference vegetation index values calculated over different time frames on Iberian rain-fed arable land. Arid Land Res Manag 26(4):271-284

Butler Jr., J.J., Kluitenberg, G.J., Whittemore, D.O., Loheide S.P. II, Jin, W., Billinger, M.A., Zhan, X., (2007) A field investigation of preatophyte-induced fluctuations in the water table. Water Resources Research 43. doi:10.1029/2005WR004627.

Calder IR (1998) Water use by forests, limits and controls. Tree Physiol 18:625-631

Dövényi Z (2010) Magyarország kistájainak katasztere [Cadastre of Small Regions in Hungary]. MTA Földrajztudományi Kutatóintézet, Budapest (in Hungarian)

Führer E, Járó Z (2005) Erdő-fa hasznosítás Magyarországon. In: Molnár S (ed) Az erdővagyon bővítése a mezőgazdaságilag gazdaságosan nem hasznosított földterületek beerdősítésével [Forest cover enlargement by afforestration of economically non rentable agricultural lands] (in Hungarian. NyME FMK, Sopron, pp 130-136

Gribovszki Z, Kalicz P, Balog K, Szabó A, Tóth T (2014) Comparison of groundwater uptake and salt dynamics of an oak forest and of a pasture on the Hungarian Great Plain. Acta Silv Lign Hung 10(1):103-114. doi:10.2478/aslh-2014-0008

Gribovszki Z, Kalicz P, Szzlágyi J, Kucsara M (2008) Riparian zone evapotranspiration estimation from diurnal groundwater level fluctuations. J Hydrol 349:6-17 https://doi.org/10.1016/j.jhydrol.2007.10.049

ljjász E (1939) A fatenyészet és az altalajvíz, különös tekintettel a nagyalföldi viszonyokra [Forest and groundwater connections in Hungarian Great Plain] (in Hungarian). Erdészeti Kísérletek 42:1-107

Jobbágy EG, Jackson RB (2004) Groundwater use and salinization with grassland afforestation. Glob Chang Biol 10:1299-1312

Jobbágy EG, Jackson RB (2007) Groundwater and soil chemical changes under phreatophytic tree plantations. J Geophys Res 112:G02013. doi:10.1029/ 2006JG000246

Kijne JW, Prathapar SA, Wopereis MCS, Sahrawat KL (1988) How to manage salinity in irrigated lands: a selective review with particular reference to irrigation in developing countries, SWIM paper 2. International Irrigation Management Institute, Colombo, Sri Lanka, p 34pp

Loheide SP II, Butler JJ, Gorelick SM (2005) Use of diurnal water table fluctuations to estimate groundwater consumption by phreatophytes: a saturatedunsaturated flow assessment. Water Resour Res 41:W07030. doi:10.1029/ 2005WR003942

Magyar P (1961) Alföldfásítás II. [Afforestration in Hungarian great plain II.] (in Hungarian. Akadémiai Kiadó, Budapest

Major P (2002) Síkvidéki erdők hatása a vízháztartásra [Effect of lowland forest on water balance] (in Hungarian). Hidrológiai Közlöny 82(6):319-324

Mátyás, CS., Sun, G. (2014) Forests in a water limited world under climate change. Environ Res Lett 9. 085001 (10pp), doi:10.1088/1748-9326/9/8/085001

Móricz, N., Mátyás, C., Berki, l., Rasztovits, E., Vekerdy, Z., Gribovszki, Z., (2012) Comparative water balance study of forest and fallow plots. iForest 5:188-196. [online 2012-08-02] URL: http://www.sisef.it/iforest/contents?id=ifor0624-005

Morton FI (1983) Operational estimates of areal evapotranspiration and their significance to the science and practice of hydrology. J Hydrol 66:1-76
Nosetto MD, Esteban EG, Paruleo JM (2005) Land use change and water losses. The case of grassland afforestation across a soil textural gradient in central Argentina. Glob Chang Biol 11:1101-1117

Nosetto MD, Jobbágy EG, Tóth T, Di Bella CM (2007) The effects of tree establishment on water and salt dynamics in naturally salt-affected grasslands. Oecologia 152: 695-705

Nosetto MD, Jobbágy MG, Tóth T, Jackson RB (2008) Regional patterns and controls of ecosystem salinization with grassland afforestation along a rainfall gradient. Global Biogeochemical Cycles vol 22:GB2015. doi:10.1029/2007GB003000

R CORE TEAM (2012) R: a language and environment for statistical computing. $R$ Foundation for Statistical Computing Vienna, Austria. ISBN 3-900051-07-0, URL http://www.R-project.org/.

Sun G, Riekerk H, Kornak LV (2000) Groundwater table rise after forest harvesting on cypress-pine flatwoods in Florida. Wetlands 20:101-112

Szabó A, Kiss K, Gribovszki Z, Tóth T (2012) Erdők hatása a talaj és altalaj sóforgalmára, valamint a talajvíz szintjére [effect of forests on the salt accumulation of soils and subsoils and on the watertable level] (in Hungarian. Agrokém Talajt 61 (1):195-209

Szilágyi J, Kovács Á, Józsa J (2012) Remote sensing based groundwater recharge estimates in the Danube-Tisza sand plateau region of Hungary. J Hydrol Hydromech 60(1):64-72. doi:10.2478/v10098-012-0006-3

Szodfridt I, Faragó S (1968) Talajvíz és vegetáció kapcsolata a Duna-Tisza köze homokterületén VVegetation and groundwater connections in Kinkunság sand areas] (in Hungarian. Bot Közlem 55(1):69-75

Tóth T, Balog K, András S, László P, Jobbágy Esteban G, Nosetto Marcello D, Zoltán G (2014) Influence of lowland forests on subsurface salt accumulation in shallow groundwater areas AoB PLANTS plu054 6:1-39. doi:10.1093/ aobpla/plu054

White WN (1932) Method of estimating groundwater supplies based on discharge by plants and evaporation from soil-- results of investigation in Escalante Valley Utah. US Geological Survey Water Supply Paper 659-A:1-105 www.dataqua.hu

\section{Submit your manuscript to a SpringerOpen ${ }^{\mathcal{O}}$ journal and benefit from:}

- Convenient online submission

- Rigorous peer review

- Open access: articles freely available online

- High visibility within the field

- Retaining the copyright to your article

Submit your next manuscript at $\boldsymbol{\wedge}$ springeropen.com 